\title{
Motivational Factors of Muslim Rape Offenders in Sungai Udang Prison, Melaka, Malaysia
}

\author{
ZAIZUL AB RAHMAN 1
}

\begin{abstract}
The issue of rape in Malaysia showed an increase from 138 cases in 1980 to the 4816 figure in 2011 and 13,272 in 2017. This leads to the need for a study to identify the criminal profile in dealing with rape, inducement factors that drive muslim rapists commit rape and knowing the rules of the rehabilation program is clearly used by prisons to rehabilitate criminals rape. Approach to field studies covering aspects of data collection procedures, instruments, research and pilot studies that spefically used in looking at factors drive these criminals commit rape and rape recovery programs in Sungai Udang Prison, Malacca. For this purpose a total of 132 muslim prisoners Sungai Udang Prison are made samples. In addition the method of sample observations and interviews with significant individuals also used in this study. The main findings of the studies obtained was the main factor for the occurence of rape sexual stimulation that is too widespread.
\end{abstract}

Keywords: Motivational Factors, Muslim Rape Offenders, Sungai Udang Prison,

The Malaysian society is frequently startled with the heinous crime of rape (Zina bi al-Ikrah) (Nik Rahim Wajis 1998) which is increasing day-to-day. Lately, the nature of rape occurring in the Malaysian society has been worrying and has led to a chain reactionary effects on other criminal cases (Zaizul 2012), like baby dumping, incest, illegitimate children and so on. Statistics by the Royal Malaysian Police (RMP) from 2014 to 2018 show that there were 577 cases of baby dumping (Berita Harian, 28 June 2019). The statistics also show that between 2010 and 2017 there was an increase in sexual crimes such as rape, amounting to 13,272 (59.7\%) cases, molest cases $(6,014$ cases or $27.04 \%)$, incest $(1,766$ cases or $8.07 \%)$, and unnatural sex $(1,152$ cases or $5.18 \%$ ) (Berita Harian Online, 27 July 2017). Meanwhile, 100,000 cases of teenage pregnancies involving girls under the age of 19 were reported since 2013 and there were approximately 900 cases of baby dumping with only $30 \%$ of the babies still alive (Sinar Harian, 10 May 2019).

According to the National Registration Department (NRD), records beginning from 2013 show that there were 159,725 cases of babies born out of wedlock or illegitimate babies registered throughout the country (Berita Harian, 12 Sept. 2016). According to the Royal Malaysian Police (RMP) statistics mentioned earlier, this phenomenon has caused us to think hard and ponder deeply about finding a solution to this problem. Studies show that the majority of victims of sexual violence are women and female children. The World health Organisation (WHO) estimates that $36 \%$ to $62 \%$ of sexual violence victims are below the age of 15 years. Rape occurs all over the world regardless of race, ethnic background, economic status, religion or culture. Most sexual and physical violence as well as psychological and emotional abuse occurs covertly and hidden from society's eyes (Shaldon 2000).

Zaizul Ab Rahman Ph. D., Senior Lecturer at the Research Centre for Theology and Philosophy, Faculty of Islamic Studies, National University of Malaysia, 43600 Bangi, MALAYSIA. Email: zaizul@ukm.edu.my. 


\section{Research Methodology}

This was a survey study on the motivational factors and rehabilitation programs concerning rapist in the Sungai Udang prison in Melaka, Malaysia. This study has two objectives, one is to identify the motivational factors that influence Muslim rapists who are incarcerated in Sungai Udang prison in Melaka. Whereas the second objective is to identify rehabilitation programs for Muslim rapists in Sungai Udang prison in Melaka.

The retrospective technique was used in this study to obtain information related to factors in the context of the respondents (Frechtling, Sharp \& Westat 1997). This study also used a combination of qualitative and quantitative methods. One advantage of a case study is that the researcher can obtain qualitative data that supports quantitative data and certain information that need qualitative description. The approach of combining two or more research methods can be referred to Frechtling, Sharp \& Westat (1997) and Creswell (2008). The quantitative method that only makes "presumptions" about feelings and relevant information are insufficient and inappropriate for describing feelings and personalities of respondents, especially in rape cases.

The questionnaire was designed based on the literature review related to the theory and concept about the motivational factors and rehabilitation programs for Muslim rapist in Sungai Ujong Prison, Melaka. The questionnaire was divided into 3 parts. Part A contains items related to information regarding the demographic background, namely gender, level of education, age, working experience, marital status and place of residence. Whereas part B contains items related to the motivational factors concept pertaining to Muslim rapists serving in Sungai Ujong Prison in Melaka, while Part C contains items related to rehabilitation programs for Muslim rapists at the Sungai Ujong Prison in Melaka

The researcher built a questionnaire by providing answers based on a 3-point Likert scale because respondents involved in rape cases mostly lacked education and many could not read or write during the questionnaire distribution session. The 3-point Likert scale is shown in the table below.

Table 1.0: Likert Scale and Marking Positions

\begin{tabular}{cl}
\hline & Scale \\
Marks & Undecided \\
3 & No \\
2 & Yes \\
\hline
\end{tabular}

Source: Adapted from Ahmad Sunawari (2011)

\section{Validity and Reliability of the Questionnaire Instrument}

Regarding the validity and reliability of the questionnaire instrument, the researcher was guided by several references, such as Chua (2006) and Creswell (2008), pertaining to the three processes of validating an instrument, namely the validity of the contents, construct and criteria. Content validity can be conducted in two ways, namely by obtaining the views of a group of respondents and experts in the related field. As for the questionnaire instrument in this study, the Content Validity was reviewed by experts comprising 10 lecturers in Islamic views attached to universities in Malaysia. The finding on the review of the content validity was .80 -1.00. The questionnaire's reliability was tested on 50 prisoners from the prison. The score for the reliability test on the questionnaire was .873, which was more than .7 and was accepted. 


\section{Study Sample}

The total number of respondents at the Sungai Udang Prison was 132. This study applied the Simple Random Sampling method to select 132 Muslim prisoners incarcerated at Sungai Udang Prison in Melaka based on the Mohd. Majid (1998) \& Suseela (2001). This sampling method was chosen because is represents all the prisoners in the Sungai Udang Prison in Melaka. According to the estimation, there were approximately 230 rapists, which is the whole population undergoing sentencing at the prison. Out of that number, 132 Muslim rapists were selected randomly as samples for studying their background based on the criteria for the actual required sample size. According to Gay \& Peter (2003), the sample size should be $10 \%$ to $20 \%$ of the population, which is sufficient for a field or descriptive study. Hence, the sample size was optimum, which was $63 \%$ of the population. The reason for choosing the Sungai Udang Prison, in Melaka as the location of the study was due to several elements. First, the Sungai Udang Prison is a prison gazetted as a prison specially for sex crime offenders from states in the Central and Southern zone. Selangor. Second, the Sungai Udang Prison is a prison for offenders undergoing sentencing. This is consistent with the objective of this study, which is to examine the role of the prison in rehabilitating prisoners convicted of rape. Third, Sungai Udang Prison is a new prison with where it is easy to access information in the form of a modern library and yearly reports.

\section{Distributing the Questionnaire}

The questionnaire was used to obtain data pertaining to the background of the prisoner's life before being sentenced to prison, their views about their past live and the present one in prison as well as the effects of rehabilitation programs carried out to rehabilitate their attitude as well as personality.

The questionnaire was distributed to respondents and they were given the opportunity to pose questions for further clarification. After all the questionnaires were returned, the researcher reviewed and checked all the questionnaires to ensure they were filled correctly and completely. Then, information in the questionnaire were analysed using Silcaru (2008). Min scores for each dimension were arranged in a descending order, from the highest min score to the lowest min score, as shown in Table 2.0 below:

Table 2.0: Interpreting the Min Score

\begin{tabular}{|c|} 
Min Score \\
\hline 2.51 to 3.50 \\
1.51 to 2.50 \\
1.00 to 1.50
\end{tabular}

Interpretation

Moderate

Low

Very Low

Source: An Adaptation from Silcaru (2008)

Meanwhile, a pilot test was carried out to test the respondent's (at the Kajang Prisons, before they were transferred to the Sungai Udang Prison) understanding of the questions found in the questionnaire. It was also intended to identify confusing items in the questionnaire and answers that cannot help to achieve the objective of this study. The pilot study also tested the reliability of the questionnaire designed by the researcher. The reliability of the questionnaire was tested during the pilot test by using a combination of two methods, namely the test-retest dan equivalent-form reliability methods, which are intended to determine the internal consistency corelation co-efficient of the items (Gole \& Thomas 1982). The researcher used the Cronbach's Coefficient Alpha, as suggested by Cronbach (1951), for measuring the reliability of the items in the questionnaire. The questionnaire was divided into 3 parts. Part A contains items https://doi.org/10.24035/ijit.20.2021.219 
related to information regarding the demographic background, namely gender, level of education, age, working experience, marital status and place of residence. Whereas part B contains items related to the motivational factors concept pertaining to Muslim rapists serving in Sungai Ujong Prison, while Part C contains items related to rehabilitation programs for Muslim rapists at the Sungai Ujong Prison. The Cronbach's alpha reliability index value for each part of the questionnaire are as shown in the table below. Based on the results of the pilot study, it was found that, overall, the reliability of the questionnaire can be accepted.

\begin{tabular}{|c|c|c|c|c|}
\hline SECTION & NO. ITEM & $\begin{array}{l}\text { CONSTRUCT } \\
\text { ITEM }\end{array}$ & VARIABLE & $\begin{array}{l}\text { ALPHA } \\
\text { VALUE }\end{array}$ \\
\hline SECTION B & $1-20$ & $\begin{array}{l}\text { Multiple Factors } \\
\text { Rehabilitation }\end{array}$ & Variable & .8122 \\
\hline SECTION C & $21-40$ & $\begin{array}{l}\text { Program } \\
\text { (Method for } \\
\text { Overcoming) } \\
\text { Effectiveness of } \\
\text { the Program }\end{array}$ & $\begin{array}{l}\text { Variable - } \\
\text { Variable }\end{array}$ & .9059 \\
\hline
\end{tabular}

\section{Findings and Discussion}

Table 5.0 shows that there are $132(100.00 \%)$ Muslims. Based on their age, the statistics show that 28 respondents $(21.3 \%)$ were $18-20$ years of age, 71 respondents (53.8\%) were 21-30 years of age and 28 respondents (7.3\%) were 31-40 years of age, 22 respondents (5.7\%) were 41-50 years of age, 5 respondents (4.7\%) were between 51-60 years of age and one respondent $(0.3 \%)$ was 61 years of age or more. Two $(0.5 \%)$ respondents did not have information about their age. This age distribution shows that majority of the respondents were aged between 26 and 39 years. Respondents' status show that 53 respondents (40.2\%) were single, 65 (49.3\%) were married, whereas $14(12.6 \%)$ were either widowers, divorced or widows. Overall, it shows that the majority were married.

DEMOGRAPHY

RELIGION (ISLAM)

AGE

18 - 25 YEARS

26 - 39 YEARS

40 - 50 YEARS

51 - 60 YEARS

STATUS

61 YEARS AND ABOVE

Table 5.0: Demographic Profile of the Respondents FREQUENCY

132

28

71

26

5

1

53

65

14
PERCENTAGE $100.00 \%$

$21.3 \%$

$53.8 \%$

$19.7 \%$

$4.7 \%$

$0.8 \%$

$40.2 \%$

$49.3 \%$

$12.6 \%$

Source: 2012 Questionnaire

\section{Motivational Factors that Affect Muslim Rapists Influencing Factors: Family and Friends}

https://doi.org/10.24035/ijit.20.2021.219 
Table 6.0: Distribution of Respondents According to Percentage, Min and Standard Deviation for Statements that Closely Measure the Influence of Family and Friends of the Muslim Rapist $(n=132)$

\begin{tabular}{lcccccc}
\hline Statement & $\begin{array}{c}\text { Agree } \\
\mathbf{( \% )}\end{array}$ & $\begin{array}{c}\text { Disagree } \\
\mathbf{( \% )}\end{array}$ & $\begin{array}{c}\text { Undecided } \\
\mathbf{( \% )}\end{array}$ & Total & Min & SD \\
\hline a. Family & $81.8(108)$ & $7.6(10)$ & $10.6(14)$ & $100(132$ & 1.29 & 0.64 \\
b. Friends & $67.4(89)$ & $18.9(25)$ & $13.6(18)$ & $100(132)$ & 1.46 & 0.72 \\
& & & & & & \\
\hline
\end{tabular}

Source: 2012 Questionnaire

Table 6.0 above shows influencing factors, such as family and friends, that affect the Muslim rapists who have been incarcerated in Sungai Udang Prison. As shown in Table 3.8, majority of the Muslim rapists (81.8\% or 108 respondents) received attention from their families compared to some $(7.6 \%$ or 10 respondents) who did not, while $10.6 \%$ (14) were undecided about the attention they received. Meanwhile, 67.4\% (89) stated that they did receive attention from friends compared to $18.9 \%$ (25) who said they did not, while $13.6 \%$ (18) were undecided.

\section{Religious Beliefs}

Table 7.0: Distribution of Respondents According to Percentage, Min and Standard Deviation for Statements that Closely Measure the Religious Beliefs of the Muslim Rapist ( $\mathrm{n}=132$ )

\begin{tabular}{lcccccc}
\hline Statement & $\begin{array}{c}\text { Good } \\
(\mathbf{\% )}\end{array}$ & $\begin{array}{c}\text { Moderate } \\
(\mathbf{\% )}\end{array}$ & $\begin{array}{c}\text { Weak } \\
(\mathbf{\% )}\end{array}$ & $\begin{array}{c}\text { Total } \\
(\mathbf{\%})\end{array}$ & Min & SD \\
\hline a. Praying & $27.3(36)$ & $30.3(40))$ & $42.4(56)$ & $100(132)$ & 2.03 & 0.76 \\
b. Reciting al-Quran & $21.2(28)$ & $31.8(42)$ & $47.0(62)$ & $100(132)$ & 2.3 & 0.79 \\
c. Fasting & & & & & & \\
d. Charity & $19.7(26)$ & $31.1(41)$ & $49.2(65)$ & $100(132)$ & 1.8 & 0.71 \\
& $16.7(22)$ & $26.5(35)$ & $56.8(75)$ & $100(132)$ & 1.9 & 0.65
\end{tabular}

Source: 2012 Questionnaire

Table 7.0 shows the four religious belief aspects held by Muslim rapists, namely performing prayers, reciting the al-Quran, fasting and charity. This study also examined the views of the perpetrators about their religious beliefs when they were carrying out their criminal act until they were eventually caught. Findings show that rapists who stated "good" for "performing prayers' were $27.3 \%$ (36), "moderate" 30.3\% (40), and "weak" 42.4\% (56). Meanwhile, for 'reciting the al-Quran', rapists who said "good" were 21.2\% (28), "moderate" 31.8\% (42) and "weak" 47.0\% (62). As for "fasting", rapists who said "good" were 19.7\% (26), "moderate" $31.1 \%$ (41) and "weak" 49.2\% (65). Lastly, for "charity", rapists who said "good" were 16.7\% (22), "moderate" 26.5\% (35) and "weak" 56.8\% (75).

\section{Habit of Consuming Alcohol, Drugs and Pills}

Table 8.0 shows the consumption of alcohol, drugs and pills by Muslim rapists. Findings indicate that $40.9 \%$ (54) of rapist agreed that they consumed alcohol before the act of rape, and $24.2 \%$ (32) of them disagreed, while 34.8\% (46) were undecided whether they consumed alcohol before the act of rape. Whereas $42.3 \%$ (56) of the rapist agreed that they consumed drugs before the act of rape and $23.7 \%$ (31) disagreed, while, 33.4\% (43) were undecided. Meanwhile, $44.6 \%$ (58) of rapists agreed that they consumed pills before the act of rape and $25.8 \%$

https://doi.org/10.24035/ijit.20.2021.219 
disagreed, while $30.8 \%$ (40) were undecided. Therefore, the habit of consuming alcohol, drugs and pills is the main factor that motivates the act of rape. The researcher opined based on the perpetrator's experience in prison that many of the perpetrators did not want to divulge information about the consumption of drugs or pills because they were afraid that their statement would jeopardise their term in prison and it could increase their prison sentences. Hence, we cannot make a conclusion about the habit of consuming drugs and pills in this case. As for the habit of alcohol consumption, the figures are comparatively big and alarming too.

Table 8.0: Distribution of Respondents According to Percentage, Min and Standard Deviation for Statements that Closely Measure the Consumption of Alcohol, Drugs and Pills by Rapists $(\mathrm{n}=132)$

\begin{tabular}{lcccccc}
\hline Statement & $\begin{array}{c}\text { Agree } \\
(\mathbf{\%})\end{array}$ & $\begin{array}{c}\text { Disagree } \\
\mathbf{( \% )}\end{array}$ & $\begin{array}{c}\text { Undecided } \\
\mathbf{( \% )}\end{array}$ & $\begin{array}{c}\text { Total } \\
\mathbf{( \% )}\end{array}$ & Min & SD \\
\hline a. Alcohol & $40.9(54)$ & $24.2(32)$ & $34.8(46)$ & $100(132$ & 2.53 & 1.33 \\
b. Friends & $42.3(56)$ & $23.7(31)$ & $33.4(43)$ & $30.8(40)$ & 2.51 & 1.31 \\
c. Pills & $44.6(58)$ & $25.8(34)$ & $30.8(40)$ & $30.8(40)$ & 2.57 & 1.35 \\
\hline
\end{tabular}

Source: 2012 Questionnaire

'Easy to Obtain Sex' and 'Late in Getting Married Due to Economic Pressure'

Table 9.0 shows two aspects of the Muslim rapist's attitude, which is 'No need to get married because it is easy to obtain sex' and 'late in getting married due to economic pressure'. Findings indicate that in relation to the first statement, 'No need to get married because it is easy to obtain sex', 17.4\% (23) agreed and 68.2\% (90) disagreed, while 14.4\% (19) were undecided. As for the 'Late in getting married due to economic pressure' statement, $46.2 \%$ (61) agreed and $44.7 \%$ (59) disagreed, while 9.1\% (12) were undecided.

Table 9.0: Distribution of Respondents According to Percentage, Min and Standard Deviation for the Statement that Closely Measures the 'Easy to Obtain Sex' and 'Late in Getting Married Due to Economic Pressure' (n=132)

\begin{tabular}{lcccccc}
\hline \multicolumn{1}{c}{ Statement } & $\begin{array}{c}\text { Agree } \\
(\%)\end{array}$ & $\begin{array}{c}\text { Disagree } \\
(\%)\end{array}$ & $\begin{array}{c}\text { Undecided } \\
(\%)\end{array}$ & $\begin{array}{c}\text { Total } \\
(\%)\end{array}$ & Min & SD \\
\hline $\begin{array}{l}\text { a. No need to get married because it is } \\
\text { easy to obtain sex }\end{array}$ & 17.4 & 68.2 & 14.4 & 100 & 1.97 & 0.56 \\
& $(23)$ & $(90)$ & $(19)$ & $(132)$ & & \\
\hline $\begin{array}{l}\text { b. Late in getting married due to } \\
\text { economic pressure }\end{array}$ & 46.2 & $44.7(59)$ & 9.1 & 100 & 1.62 & 0.65 \\
\hline
\end{tabular}

Source: 2012 Questionnaire

\section{Main Motivational Factors that Encourage Muslim Rapists to Commit Rape}

Table 10.0: Distribution of Respondents According to Percentage, Min and Standard Deviation for the Statement that Closely Measures the Main Motivational Factors that Encourage Rapist to Commit Rape $(\mathrm{n}=132)$. 


\begin{tabular}{|c|c|c|c|c|c|c|}
\hline & (\%) & (\%) & (\%) & & & \\
\hline $\begin{array}{l}\text { a. Widely available sexual } \\
\text { stimulants. }\end{array}$ & $80.3(106)$ & $12.1(16)$ & $7.6(10)$ & $100(132$ & 1.30 & 0.71 \\
\hline b. Watching Pornography. & $87.9(116)$ & $10.6(14)$ & $1.5(2)$ & $100(132$ & 1.14 & 0.39 \\
\hline $\begin{array}{l}\text { c. First time watching } \\
\text { pornography was }\end{array}$ & $68.9(91)$ & $28.8(24)$ & $2.3(3)$ & $100(132)$ & 3.54 & 1.03 \\
\hline $\begin{array}{l}\text { between 13-18 years old. } \\
\text { d. Solicited prostitutes } \\
\text { after watching } \\
\text { pornography. }\end{array}$ & 38.7 (51) & $34.1(45)$ & $27.2(36)$ & $100(132)$ & 1.44 & 0.73 \\
\hline $\begin{array}{l}\text { e. Masturbating after } \\
\text { watching pornography. }\end{array}$ & $33.9(44)$ & $20.5(27)$ & $46.2(61)$ & $100(132)$ & 1.63 & 0.83 \\
\hline f. Pre-marital sex. & $71.2(94)$ & $18.9(25)$ & $9.9(13)$ & $100(132)$ & 1.45 & 0.86 \\
\hline g. Extramarital sex. & $45.5(60)$ & $40.2(53)$ & $14.4(19)$ & $100(132)$ & .75 & 1.07 \\
\hline h. Sexy women. & 75.0 (99) & $16.7(22)$ & $8.3(11)$ & $100(132)$ & 1.33 & 0.63 \\
\hline
\end{tabular}

Based on Table 10.0, 80.3\% (106) of the Muslim rapists agreed that 'widely available sexual stimulants' had caused them to commit rape, compared to $12.1 \%$ (16) who disagreed, while 7.6\% (10) were undecided. 87.9\% (116) agreed that 'watching pornography' played a major role and $10.6 \%$ (14) disagreed, while $1.5 \%$ (2) were undecided. As for 'first time watching pornography was between 13-18 years old', 68.9\% responded with a yes and $28.8 \%$ (24) responded with a no, while $2.3 \%$ (3) were undecided.

As for activities they performed after watching pornography, 38.7\% (51) said they solicited prostitutes and $34.1 \%$ (45) did not, while $27.2 \%$ (36) were undecided. Whereas, $33.9 \%$ (44) said that they masturbated after watching pornography and $20.5 \%$ (27) said they did not, while $46.2 \%$ (61) were undecided. Regarding 'pre-marital sex', the rate was high with $71.2 \%$ (94) agreeing and 18.9\% (25) disagreeing, while 9.9\% (13) were undecided. 45.5\% (60) agreed that they had had extra-marital sex and $40.2 \%$ (53) said they had not, while $14.4 \%$ (19) were undecided. For the majority, 'sexy women' was also a factor with $75.0 \%$ (99) agreeing it affected them and $16.7 \%$ (22) disagreeing, while $8.3 \%$ (11) were undecided.

Nevertheless, this is one thing that warrants serious attention since studies in the West have found that sexual offenders face problems in forming social relationships (Frank 1990) and this leads to them feeling isolated and lonely. Some researchers opined that these weaknesses in forming social relationships gets them involved in sexual relations with minors (Larson 1993). Hence, sexual offenders feel that they can have better relations with minors compared to adults, which motivates them to carry on committing this unlawful act. These social relationships require serious attention although not many offenders have admitted to it (Riggins 2003).

Findings indicate that many factors lead to the crime of rape. What is clear is that a weak faith and religious beliefs are the main factors that contribute to rape. The table shows that Muslim rapists comprise those who have weak religious beliefs, moderate in religious practices and strongly propagate religion. Attention and monitoring by parents are also important as the table indicates that those who lack these elements and have been socially mixing without supervision are the ones most vulnerable to be involved in rape cases. This is because parents these days are busy with work due to an increase in the cost of living although the majority of Muslim rapists are usually friends from the same village. This causes stress in them and they seek entertainment with friends outside their village, which drags them into promiscuous activities and eventually get involved in rape. The level of education indicates that many of them lack a high level of education. Findings show that it is not necessary to have a high level of education or a strong faith but they have far higher level of thinking. This is because spas, GRO, 
and prostitution clubs are springing daily although enforcement by government agencies have been rampant but the demand from society for these kinds of services is equally rising. This could be due to better and higher paid positions and vocations that allow them to frequent these places. Another factor could be that parents these days only emphasise on academic achievements minus the emphasise on religion. Children feel the stress and pressure caused by the hope and pestering of parents who prioritise academic success as a yardstick for success in life without balancing religious elements as a shield against challenges in this modern era.

According to Hurlock (2007), in order to avoid getting involved in crime, one should put the family as the core element when building a society. The family is often associated with the mother and father who act as guards that control the movement of family members under them. Children will easily follow the norms set by the parents so much so that the rules and regulations begin to influence their behaviour when they become adults.

According to Mead (2002), a sociologist, culture and a conducive social circle will produce stable mental health among members of society. Humans with a stable mental health are inclined to do positive things. Mohd Nasir et al. (2021) mentioned that the family plays an important role in balancing social values. He asserted that the family functions as a controlled facility for forming physical relations and experiences that are first formed through emotional interrelations between family members. The family provides awareness that living as a family provides space for educating members of society to live with others and respect the feelings of others.

This study only focused on Malay prisoners since $100 \%$ of rape-related prisoners in Sungai Udang Prison were Muslims. According to the interview with the Director of the Sungai Udang Prison, $85 \%$ of rape cases involving the Chinese and Indians are settled out of court. They pay compensation to the victim's family for the case to be withdrawn. Majority of rape victims' families are Malays and they do not want to receive compensation from the perpetrator so as to safeguard their dignity and that of the family. The Malays treasure their dignity and believe that it cannot be bought or sold. Moreover, many of the them do not have the capability to pay compensation when compared to other races. That is the reason why statistics concerning the Malay are more prominent compared to the other races.

Exposure to extreme sex and easy accessibility to pornographic materials (pornographic videos and websites), convenience in downloading pornographic materials in the mobile phones, magazines as well as the flood of prostitution hubs, massage parlours, and karaoke centres plays a vital role in contributing towards the rise in rape cases. Majority of rapists admit that they were influenced by these elements and many of them began to watch pornographic materials when they were 13 years old, right up to when they were 30 years old. Most of them admitted that after watching these pornographic materials they masturbated or solicited prostitutes.

Bandura (2001) explained that the aggressive behaviour portrayed by children is an important instrument in social learning theory that they tend to experience. Women who frequently become models or promotion symbols and sex attractions that are the attractions in sexual violence though the copying of violent sexual acts found in videos, which are repeatedly viewed, lead to extraordinarily high levels of sexual lust. Frank (1990) found that a person's behaviour is based on an imbalance in the chromosomes. A male human with the xyy chromosome is more aggressive and has a greater probability to commit criminal acts compared to a male who has the $X Y$ chromosome

Throughout this study involving rapists incarcerated in the Sungai Udang Prison, observations were made regarding rapists' personality based on the type of body shape. Most of them had a study body, average height, tan skin, heavy eyebrows, long and thin fingers and an attractive appearance. This is consistent with Shaldon (2000), who opined that the physical shape of the body also plays a role in a person's personality and behaviour. He divided body shape into three types, namely soft and rounded (endormorphic), study and tall (mesomorfhic)

https://doi.org/10.24035/ijit.20.2021.219 
and thin (ectomorphic). His study on 200 prisoners had found that the mesomorfhic individual has a strong tendency in getting involved in criminal behaviour compared to the others.

According to an Italian criminologist named Lambroso (1998) and his study involving criminal behaviour, a person is born a criminal or is a descendent of criminals. According to his discovery theory, a criminal can be classified into three classes, namely, to be born a criminal, an insane criminal or a common criminal. His findings in a hereditary study involving 1,200 members of the Jukes family, found that 140 family members were criminals, 7 were found to be murderers, 60 were thieves, and the remainder were prostitutes. This study shows that more than $10 \%$ from one family were involved in crime. Similarly, findings by another criminologist named Della Porte (1996) had examined the relationship between body type and type of crime committed. According to the theory, he could identify a thief by looking at the physical aspects, such as a small ear, heavy eyebrows, small nose, and movement and look of the eyes, think lips as well as small and long fingers.

A study at the Virginia prison had compared sexual cases between 75 offenders of various cases. It was found that most of the rapists had very strong sexual inclinations compared to non-rape offenders (Russell 1986).

Findings show that, majority of Muslim rapists are positive about the rehabilitation programs in the prisons, especially religious programs. Whereas, canning and jail terms were very effective, according to the prisoners, with 86 (59.31\%) prisoners agreeing that it is effective. This study also found that $122(84.13 \%)$ prisoners agreed that they have become penitent and would refrain from past undesirable activities. $110(83.0 \%)$ of them were very confident that they would return to society and make good their undesirable activities of the past. What is certain is that only the society can accept ex-prisoners with an open heart and a positive mindset in order to achieve a country with a zero-crime rate in the future. Findings also show that there are various motivational factors among the rapist. It is strongly indicated that lack of religious education and excessive exposure to pornographic materials are the main causes of rape. This happens because these rapists lack a strong faith and this is in tandem with the influence of excessive pornographic materials that are easily obtainable making it difficult for them to be rational when controlling their basic human sexual instincts and channelling them through the institution of marriage.

\section{References}

Ahmad Sunawari Long. 2011. Pengenalan Metodologi Penyelidikan Pengajian Islam. Bangi: Universiti Kebangsaan Malaysia.

Bandura. 2001. The universality of rapist. The Journal of Psychohistory. 19(2): 45-87.

Chua, Y.P. 2006. Kaedah dan Statistik Penyelidikan: Kaedah Penyelidikan Buku 1. Kuala Lumpur: McGraw Hill Education.

Creswell, J.W. 2008. Education Research: Planning, Conduction and Evaluating Quantitative and Qualitative Research. New Jersey: Pearson Education, Inc.

Cronbach, L. J. 1951. Coefficient alpha and the internal structure of tests. Psychometrika. 16, 297-334.

Della Porte, Babtiste. 1996. Ten year research update review: child sexual abuse. Journal of the American Academy of Child \& Adolescent Psychiatry. 42 (3): 23-45.

Frank, Scarpilti. 1990. Human Behavior in the Social Environment. Itasca: F.E. Peacock Publishers, Inc.

Frechtling, Sharp \& Westat (Editors). 1997. User-friendly Handbook for Mixed Method Evaluations. Arlington: National Science Foundation.

Gay, L. R. \& Airasian, Peter. 2003. Educational Research: Competencies for Analysis and Applications. New Jersey: Merrill Prentice Hall. 
Gole, H. Roid \& Thomas, M. Heldyna. 1982. A Technology for Test - Item. New York: Harcort Brace Joronarich Publishers.

https://www.bharian.com.my/berita/nasional/2019/06/578922/kes-pembuangan-bayiserius-tpm. Retrieved: 12 June 2018.

https://www.sinarharian.com.my/article/27518/BERITA/Nasional/100000-kes-remaja-hamildilaporkan-sejak-2013. Retrieved: 12 June 2018.

Hurlock. 2007. Systems theory sexual sexual predator: focus on families and communities. Final Report for National Institute of Justice. New York, NY: John Wiley and Sons, Inc. 3 (4): 321-354.

Lambroso, Cesare. 1998. Understanding Sex Offender, Evaluation and Treatment. New York: The Gullford Press.

Larson, Lisa R.. 1993. Betrayal and repetition: understanding aggression in sexually abused girls. Clinical Social Work Journal. 21, 137-150.

Mead. 2002. Child sexual abuse preventions programs: evaluating "who do you tell". Child sexual abuse \& neglect. The International Journal of Sexual. 21(9): 867-881.

Mohd. Majid Konting. 1998. Kaedah Penyelidikan Pendidikan. Kuala Lumpur: Dewan Bahasa dan Pustaka.

Mohd. Nasir Omar, Ahmad Sunawari Long, Abdull Rahman Mahmood \& Ab Rahman, Z. 2021. Islamic notion of happiness (al-sa'ada): an analysis of Miskawayh's thought. International Journal of Islamic Thought. 19: 49-57. https://doi.org/10.24035/ijit.19.2021.195.

Nik Rahim Wajis. 1998. Jenayab rogol di dalam undang-undang Islam. Jurnal Syariah. 6 (2): 73 80.

Riggins., Leah. 2003. Criminalizing Marital Rape in Indonesia. http://www.bc.edu/schools/law/lawreviews/meta-elements/journals. 18(2): 45-76.

Russell, Diana E. H. 1986. The Secret Trauma in The Lives of Girls and Women. New York: Basic Books, Inc. Publisher.

Shaldon, William H. 2000. Child sexual abuse. In, Martin D. (Ed), The Blackwell Encyclopaedia of Social Work. Oxford: Blackwell Publishers Inc.

Silcaru, T. 2008. Analisis Statistik SPSS. Nontaburi: S.R. Printing Mass Produk Sdn. Bhd.

Suseela Malakolunthu. 2001. Pengumpulan dan analisis data kualitatif: satu imbasan. In, Marohaini Yusoff. (ed.). Penyelidikan Kualitatif Pengalaman Kerja Lapangan Kajian. Kuala Lumpur: Penerbit Universiti Malaya.

Zaizul Ab. Rahman. 2012. Faktor Dorongan Penjenayah Rogol Muslim di Malaysia dan Program Pemulihannya: Kajian di Penjara Sungai Udang. Tesis PhD, Bangi Jabatan Dakwah dan Pembangunan Insan, Akademi Pengajian Islam, Universiti Malaya, Kuala Lumpur. 